\title{
FOCUS AND QUESTION FORMATION IN EDO*
}

\author{
Thomas O. Omoruyi \\ University of Benin
}

\begin{abstract}
The purpose of this study is to investigate the relations that hold between sentence constituents in focus constructions and the derivation of questions which involve focussing. We observe that word-order change plays a fundamental part in focussing as the elements in focus are moved to a sentence-initial position. As a result, these elements which are spoken about, questioned, or negated are made explicit. We examine the syntactic operations which occur when subject nouns, direct and indirect object nouns, genitival constructions, beneficiaries, locations, instruments and manner are focalized. Finally, we examine the derivational processes for polar and non-polar quesitons and the role focussing plays in eliciting appropriate responses from the hearers.
\end{abstract}

\section{Introduction}

Focussing is a widespread phenomenon in Edo. ${ }^{1}$ It involves a reordering of some sentence constituents with a view to bringing them into prominence, hence such sentences are labelled emphatic sentences. In stress-timed languages such as English, an emphatic stress on constituents of a sentence usually brings such constituents into focus, but in syllable-timed and tone languages, emphatic stresses

\footnotetext{
* I would like to thank Professor J.S. Gruber and Mr. Matt Aikhionbare for their valuable comments on the ideas put forward in this paper. I am greatly indebted to Professor Russell G. Schuh who revealed to me several errors in an earlier draft. None of these people are responsible for any error that may still exist. This paper builds on an earlier work, Qmoruyi [in press]. The syntactic processes for the formation of focus constructions and how they relate to question formation were not fully investigated in that paper because of the limitation of space.

${ }^{1}$ Edo (also called Bini) is the main language of the ancient Kingdom of Benin in Nigeria. It is classified by Elugbe [1979] as a member of the Edoid group of languages within the Kwa subgroup of Niger-Congo languages. The data for this study have come largely from our native speaker competence in the language. We, however, consulted many informants whenever we had reasons to distrust our intuition.
} 
and tone do not appear to be productive devices for focalization because every syllable corresponds to a unit of stress and tone.

Passivization, which serves as a device for bringing some nouns into prominence in some languages, does not occur in Edo, but the prevalence of focussing compensates for the nonoccurrence of this device. Focussing also functions as a means of introducing new arguments or information into a discourse and also for correcting false information. As Welmers [1973:43] rightly observes, it is in topicalized or focus constructions that the full forms of Edo verbs are realized. The final vowels and suffixes of verbs are not elided in object-focus constructions in which the verbs occur sentence-finally. And finally, we observe that elements about which a questioner seeks information are clearly identified in questiontypes which involve focussing. This is particularly helpful to the hearer in the choice of appropriate responses to questions.

First, we shall examine the syntactic processes for the formation of focus constructions and their semantic interpretations in Edo. We shall then proceed to examine how focus constructions, question formation, relativization, and so on, commonly operate together.

\section{Focus in Declarative Sentences}

Edo focus constructions are synonymous with English cleft sentences [Schachter 1973]. According to Quirk et al [1972:951] a cleft sentence is

"...a special construction which gives both thematic and focal prominence to a particular element of the clause in the cleft sentence, so called because it divides a single clause into two separate sections, each with its own verb."

Edo is basically an SVO language, and it is from this structure that focus constructions are derived. The element in focus occurs sentence-initially, and it is followed by a focus marker which consists of a third person singular pronoun $\dot{e}$ or $\phi$ and the copula ré. Other syntactic processes, which we shall examine shortly, occur depending on the element that is focalized.

2.1. Subject focus. Subject nouns occur sentence-initially in non-focus constructions as follows: 2

${ }^{2}$ All examples are cited in the Edo orthography proposed by Amayo and Elugbe [1983]. The oral vowels $i, e, e, a, \rho, 0$, and $u$ correspond approximately to $/ \mathrm{i} /, / e /, / \varepsilon /, / a /, / \partial /, / 0 /$ and $/ u /$ respectively. Nasalized vowels are marked by a following nasal consonant as follows: in $=\Lambda /$, en $=\mid \varepsilon /$, an $=/ \& /$, on $=/ 5 /$ and $u n=10 /$. When a nasal consonant precedes a nasalized vowel, it is unmarked by $n$. Digraphs are used as follows: $v b=/ v /, m w=10 /, \pi r=/ r /, r h=/ r /, \mathrm{kp}=/ \mathrm{kp} /, \mathrm{kh}$ $=\mid x /, g h=/ \gamma /$, and $g b=/ g b /$. 

$\begin{array}{lll}\text { (1) Osàr } \emptyset & \text { bழ } & \text { dwá } \\ \text { Osaro build } & \text { house }\end{array}$
'Osaro built a house'

A leftward movement of the subject noun occurs when it is brought into focus and it is optionally followed by the focus marker è re or $\dot{\partial}$ ré 'it be'. Finally, the third person singular pronoun $\phi$ 'he/she/it' fills the gap from which the subject noun has been moved. Following these processes, (1) will be realized as (2) below:
(2)
Osàró (è ré) $\oint$ b
Osaro it be PRO build house
'it is Osaro who built a house'

When the focus marker is deleted as is often the case in rapid speech, it is the occurrence of the third person singular pronoun, which we call PRO below, that indicates that the subject noun is focalized. This pronoun is always $\phi$ regardless of the number, gender, and person of the subject noun in focus.

The occurrence of a slot filling third person pronoun in a subject focus sentence has also been attested in Yoruba. According to Bamgboșe [1967:37], "when the subject is moved to the initial position of the clause, a third person pronoun must be substituted for it." It is, however, an invariable pronoun in the case of Edo subject focus constructions. As a result, the following are grammatical focus constructions even though the pronouns in focus do not share the same person and number features as the PRO.
(3) a. iran (è ré) $\emptyset \quad b \phi$ bwa
they it be PRO build house
b. wę (è ré) $\emptyset$ dé íkękę 'it is you that bought a bicycle' you(sg) it be PRO buy bicycle

Amayo [1975] calls this third person singular pronoun which occurs in subject focus sentences a "subject concord marker". He argues further that subject concord markers (SCM) and auxiliary markers (AM) are inherent parts of Edo verbal constructions (VC). Among others, he illustrates with the following sentence (= (23) in Amayo [1975]) in which the focus marker is deleted:

(4) ird 6 gha rre
they SCM AM come

'it is they who would have come'

Amayo may have come to this conclusion because what appears to be SCM's have been attested in some Edoid languages. However, their syntactic behaviour in 
these languages is different from the Edo case. Consider the following non-focus constructions in Yephee (Etsako): 3

(5) a. Oggèlé $\phi$ dé ùkpo

Ogele PRO buy cloth

'Ogele bought a piece of cloth'

b. Ógèlé làgi Àdàmú é dẹ ikpo

Ogele and Adamu PRO buy clothes

'Ogele and Adamu bought pieces of cloth'

The pronouns $\phi$ in (5a) and $\varepsilon$ in (5b) agree in number with the subject nouns. When these nouns are brought into focus, the result is as follows:

(6) a. Oggèlę li $\phi \quad d \hat{~ u k p o ̀ ~}$

Ogele it-be PRO buy cloth

'it is Ogele who bought a piece of cloth'

b. Ógèlé làgi Àdàmú lí é dé ikpò Ogele and Adamu it-be PRO buy clothes

'it is Ogele and Adamu who bought pieces of cloth'

Sentence (5a) is a non-focus construction which is similar to Edo focus constructions when the focus marker è ré 'it be' is deleted. The pronoun (PRO) does not occur in Edo non-focus constructions. Therefore, its occurrence must be attributed to subject focus. As it does not often manifest any concord and agreement with the antecedent noun, we feel that it is a misnomer to call it a subject concord marker. Subject concord marking is commonly associated with noun class languages and Ędo does not belong to this category.

Following Awoyale [1985], we shall call this third person pronoun a "procopy". He observes in the Yoruba case that when a subject noun "is shifted to the front...a pro-copy is left in its place". This is an adequate description of the syntactic process in Edo. However, it should be noted that the pro-copy may not possess the features of the antecedent noun in terms of number and person. Gender does not play any role in Edo pronominalization processes.

2.2. Object and genitive focus. Whenever a direct object of a monotransitive verb is focalized, it occurs at a sentence-initial position, and then it is op-

3I am grateful to Mrs. Grace Masagbor for the data on Yekhee (Etsakq). 
tionally followed by the focus marker. Unlike the subject focus case discussed above, no pro-copy fills the place from which the direct object is moved. For example, (1) will be realized as follows:
(7) dowá (ę ré) Osàró bọrè
'it is a house Osaro built'
house it be Osaro build+Past

The simple past suffix -rè and its phonologically conditioned variants (see Omoruyi [1986a]) do not occur when a verb is directly followed by an object noun. The noun dwa 'house' in (7) now assumes the grammatical status of a subject noun. This new grammatical function is aptly demonstrated when an object pronoun is focalized; it obligatorily changes to its subject pronoun counterpart. ${ }^{4}$ Consider the changes that occur in the following non-focus and focus constructions:
(8) a. Osàgié tiè rùé
Osagie call you (sg.)
'Osagie called you'
b. wè (è ré) Osàgie tiérè 'it is you that Osagie called' you(sg) it be Osagie call+Past

The object pronoun rùe in (8a) obligatorily becomes wè in (8b) as it is now a subject pronoun. Since it is the noun or pronoun in focus that the speaker is actually talking about, it assumes the role of a subject noun or pronoun. The transitivity of the verb, however, gives clues that it is a direct object that "is transposed to the beginning of the sentence and the verb appears in sentence-final position" [Welmers 1973:43].

When direct and indirect object nouns of ditransitive verbs are brought into focus, a resumptive pronoun ęrè 'him/her/it' fills the gap created by the movement of these nouns. 5 For example:

(9) a. iràn má Òsàgié ègiè

'they made Osagie a king' they make Osagie king

b. Osàgie (ę ré) íràn má ȩrè ègiè 'it is Osagie they made a king' Osagie it be they make PRO king

${ }^{4} \mathrm{~A}$ full description of Edo subject and object pronouns occurs in Qmoruyi [1986b]. Object pronouns are also used in genitival constructions.

${ }^{5}$ See Safir [1986] for a discussion of how resumptive pronouns are bound in sentence structures. 

c. ègiè (è ré) íràn má Osàgié ệrè 'it is a king they made Osagie' king it be they make Osagie PRO

The focalized nouns are coindexed with the resumptive pronoun ęrè. A similar pronoun occurs in genitival constructions. A possessed noun usually occurs before the possessor and the two can be moved together to a sentence-initial position. However, if the possessed noun or the possessor alone is focalized the pronoun érè or its variant órè must occur in the second part of the clause. For example:

(10) a. iràn guọghọ ikệkẹ Òsàró they destroy bicycle Osaro

'they destroyed Osaro's bicycle'

b. íkẹké Osàrọ (è ré) îràn guọghợè bicycle Osaro it be they destroy+Past

'it is Osaro's bicycle that they destroyed'

c. Ósàrọ (è ré) íràn guọghhọ íkẹkké ęrè Osaro it be they destroy bicycle PRO

'it is Osaro whose bicycle they destroyed'

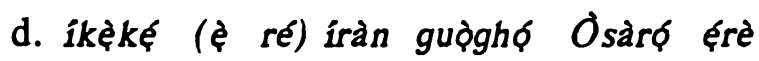
bicycle it be they destroy Osaro PRO

'it is a bicycle belonging to Osaro that they destroyed'

The word érè which occurs in (10c) and (10d) functions as a possessive pronoun. Object pronouns also perform this function in Edo.

2.3. Focus on objects of prepositions. Some syntactic changes occur when a noun preceded by a preposition is focalized. Consider the predicate of the following non-focus sentence:

(11)
Ozo khuẹrè vbè èzè
Ozo bathe+Past in river
'Ozo had a bath in the river'

Because eेzę 'river' is not directly dominated by the verb, it is possible for the simple past suffix -rè to occur. Therefore, èzeे is the object of the locative 
preposition vbe 'in'. Of course, it is also possible for a direct object of a verb to be followed by a prepositional phrase as follows:

(12) íràn mi èvbàré vbè úwú dwá they eat food in inside house 'they ate food inside the house'

When stationary or specific locations such as vbè èzę in (11) and vbè úwú dowá in (12) are focalized, the preposition vbè is deleted and a locative marker (LOC) ná obligatorily precedes the verb. The occurrence of the simple past suffix is then blocked. Thus, (11) and (12) will be realized as (13a) and (13b) respectively.
a. èzzè (è ré) Ozó ná khué river it be Ozo LOC bathe
'it is in the river that Ozo had a bath'
b. úwú dwa (è ré) iràn ná rrí èvbàré
inside house it be they LOC eat food
'it is inside the house that they ate food'

However, if the location is not specific vbè and ná can co-occur. For example:
a. Lyáyì dé ếwù vbè ddẹ
Iyayi buy shirt on way

'Iyayi bought a shirt on the way'

b. vbè ddẹ (è ré) lyáyì ná dẹ éwò on way it be Iyayi LOC buy shirt

'it is on the way that Iyayi bought a shirt'

In another sense, vbè marks the time of an event and when the event is brought into focus a sequence marker (SQM) ná occurs in the second clause. For example:

(15)
a. Ozó dé vbè ò khué
Ozo fall while he bathe
'Ozo fell while bathing' 
b. vbè ò khuẹ (è ré) Ozó ná dé while he bathe it be Ozo SQM fall

'it was while bathing that Ozo fell'

In other locative focus constructions, yè becomes yi when its object is focalized and the preposition occurs sentence-finally.

a. Ozó tótà yè ágá

Ozo sit on chair

'Ozo sat on a chair'

b. ágá (è ré) Ozó tótà yì

chair it be Ozo sit on

'it is a chair Ozo sat on'

Similarly, the preposition nè becomes nà when a beneficiary is brought into focus and the preposition occurs sentence-finally.

a. Osàgié bọ òwá nè Osàró

Osagie build house for Osaro

'Osagie built a house for Osaro'

b. Osàrọ (è ré) Òsàgié bọ dwá nà

Osaro it be Osagie build house for

'it is Osaro who Osagie built a house for'

However, focus on instrument and manner follows similar processes of direct objects of monotransitive verbs described above. No pro-copy or resumptive pronoun occurs after focalization. For example:

a. íràn yá ísánhę̀n kiè èkhù they use key open door

'they used a key to open the door'

b. ísánhę̀n (è ré) íràn yá kiè èkhù key it be they use open door

'it is a key they used in opening the door' 
(19) a. Odé yá dhò gbé òmó nií

Ode use anger beat child that

'Ode beat that child in anger'

b. ohù (è ré) Òdé yá gbé òmó nî́ anger it be Ode use beat child that

'it is in anger that Ode beat that child'

(20) a. Ozó khián zàizài

Ozo walk briskly

'Ozo walks briskly'

b. zàizài (è ré) Ozó khián

briskly it be Ozo walk

'it is in a brisk manner that Ozo walks'

2.4. Verb focus. Verbs cannot be focalized directly like subject and object nouns. In order to focalize an action or state expressed by a verb, a nominal must first be derived from it. The derived nominal is moved to the front and the verb occurs in the second part of the sentence.

All Edo nouns begin and end with vowels while verbs begin with consonants and end with vowels. Two methods are employed in the derivation of nominals from verbs. The first method is by the prefixation of oral vowels to verb stems. There are no phonological rules for the choice of vowel prefixes. For example:

\begin{tabular}{|c|c|c|c|}
\hline khiàn & 'to walk' & òkhián & 'walk' \\
\hline gię & 'to laugh' & dgię & 'laughter' \\
\hline tuę & 'to greet' & d̀tué & 'greeting' \\
\hline hiọ & 'to urinate' & àhió & 'urine' \\
\hline fó & 'to perspire' & $\phi f \phi$ & 'perspiration' \\
\hline khuę & 'to bathe' & àkhuę & 'bath' \\
\hline$m$ węेmwę & 'to be mad' & èmwęmwę & 'madness' \\
\hline
\end{tabular}

The second method involves the affixation of the discontinuous morpheme u- $\boldsymbol{m}$ wę to a verb stem. For example:

(22)

$\begin{array}{llll}\text { fo } & \text { 'to end' } & \text { ưfómwè } & \text { 'ending', } \\ g b e & \text { 'to beat' } & \text { ùgbémwè } & \text { 'beating' } \\ g \delta & \text { 'to shout' } & \text { ugómwę } & \text { 'shouting' }\end{array}$



tàn
kpф16
'to be long'
'to be big'
ùtánmwè 'length'
ùkpølómwè 'bigness'

The (b) sentences below are focus constructions which are derived from the (a) sentences.

(23)
a. Ozó tuę mwè
Ozo greet me
'Ozo greeted me'
b. dtuę (è ré) Ozó tuę mwè greeting it be Ozo greet me
'it is greeting that Ozo greeted me'

(24) a. íràn gá Oànóbuà

they serve God

'they serve God'

b. ùgámwę (è ré) íràn gá Òsànóbuà serving it be they serve God

'it is serving that they serve God'

We observe, however, that not all verbs can be brought into focus through a nominalization process. For example, the verbs $m$ wèę 'have' and ré 'be' cannot be nominalized. As we shall discover later, there are other problems when we attempt to focalize and question a verb.

2.5. Negative focus construction. In all the affirmative focus constructions we have examined so far, we observed that the occurrence of the focus marker eेré or $\phi$ ré is optional. In negative focus constructions its occurrence is obligatory. The negative particle $\dot{i}$ is cliticized to the pronoun $\dot{\xi}$; the variant $\dot{\phi}$ never occurs with the negative particle. The element in focus which is also now negated occurs after the copula ré and this places it within the scope of negation. For example, a negation of (2) which we repeat here as (25a) will result in (25b).

(25)
a. Osàr (è ré) $\emptyset$ bழ dwá
Osaro it be PRO build house
'it is Osaro who built a house' 


\section{b. èi ré Osàró $\phi$ bழ dwa it-NEG be Osaro PRO build house \\ 'it is not Osaro who built a house'}

A negation of the object focus sentence in (7) which we repeat here as (26a) will result in (26b).
a. dwá (è ré) Osàró bọrè
house it be Osaro build+Past
'it is a house Osaro built'

b. ¿̇i ré dwá Osàró bọrè
it-NEG be house Osaro build+Past

'it is not a house Osaro built'

All elements that can be focalized can also be negated through this process.

\section{Relationship Between Focus and Question Formation}

In this article, we shall restrict ourselves to the so-called yes/no and WH-questions. Following Emenajo [1979], we shall call yes/no questions polar questions and WH-questions non-polar questions. It is the way these questions are asked that determines felicitous responses. We shall argue that focussing obligatorily occurs in non-polar questions, so natural responses must also be in the form of focus constructions. We shall first examine polar questions in which focussing is optional.

3.1. Polar questions. Our data suggest that there are three principal methods of forming polar questions in Edo. A natural response to them must commence

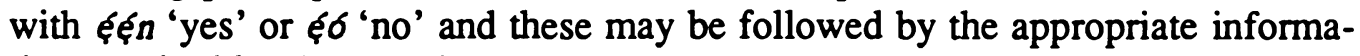
tion required by the questioner.

Focussing in a polar question is only a stylistic device for bringing a constituent being questioned into prominence. However, if the questioner decides to bring any constituent into focus, the hearer must reply in a focus construction.

3.1.1. Raised pitch. Statements can be changed to questions when the pitch, especially on the final syllable, is raised. Such questions also usually commence with a high tone which is traceable to the emphatic particle té. It occurs sentenceinitially and Agheyisi [1986] translates it as 'it is the case that ...' but in a question formation it can be translated 'is it the case that ...?' In our literal translation we shall simply call it EMPH (emphasizer). The pitch differences between a 
statement and a question, which coincides with the tonal level, can be represented as follows:

(27)
a. $[$ -

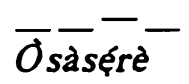
khuę
EMPH
Osasere
bathe

'it is the case that Osasere is bathing'

b. [

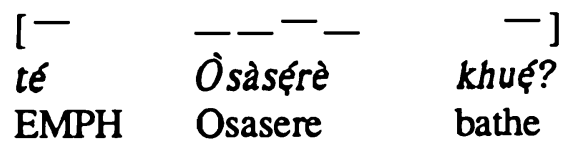

'is it the case that Osasere is bathing?'

If the emphasizer is deleted, the following pitch changes can occur:

(28)

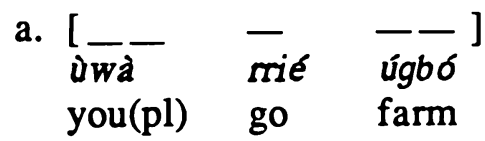

'you are going to the farm'

$\begin{array}{lll}\text { b. }\left[\begin{array}{lll}- & - & --\end{array}\right] \\ \text { úwà } & \text { rrié } & \text { úgbo? } \\ \text { you(pl) } & \text { go } & \text { farm }\end{array}$

'are you going to the farm?'

We can begin the translation of (28b) with 'is it the case that ...?'. This is because òwa 'you(pl)' normally bears two low tones but if té is deleted sentenceinitially, the floating high tone left behind displaces the initial low tone in ivà.

As a sentence emphasizer, té can only occur in the basic SVO sentence-pattern. If any element is already in focus té cannot occur. For example, the following sentence which is derived from (28a) is ungrammatical:

*té $\quad$ iwà $\quad$ (è ré) $\emptyset$ rié úgbo

EMPh you(pl) it be PRO go farm

'it is the case that it is you going to the farm'

The ungrammaticality of (29) is due to the fact that it is illogical or self-contradictory to emphasize a sentence constituent by focussing it and at the same time 
emphasize the whole sentence. However, if a sentence is negated, the focus marker and the negator can co-occur with te. When this happens, it is the whole sentence that is in focus. No movement occurs so neither a procopy nor a resumptive pronoun replaces any element. For example:

(30) èi ré té ìwà rrié úgbó?

it-NEG be EMPH you(pl) go farm

'is it not the case that you are going to the farm?'

Finally, we observe that statements turned into questions by a raised pitch are commonly accompanied by some paralinguistic features which make it clearer to the hearer that some information is sought from him.

3.1.2. Formation with $y$ f. Again, a statement can be turned into a question by placing the tag $y^{i}$ at the end of it. It has no meaning of its own; it only functions as a question marker so we shall gloss it as $Q$ in the following example:

(31)
íràn tié èbé yí?
'are they reading a book?'

they read book $Q$

An emphatic sentence which begins with té can also be changed into a question when $y^{\prime} i$ is placed at the end of it. For example:

(32) té

té Ozb lé èvalre yí? 'is is the case that Ozo is cooking?'

EMPH Ozo cook food $Q$

The question particle $y^{i}$ can occur in all focus constructions. For example, the object noun is focussed and questioned in the following sentence:

(33) èbé (è ré) íràn tié yí? book it be they read $Q$

As earlier observed (see 29), te cannot occur in this sentence structure. An appropriate response must also bring the object noun into focus. For example, an affirmative response will be as follows:

(34) द̧̧̧̧n, èbé (è ré) î̀àn tié yes book it be they read

'yes, it is a book that they are reading'

The following response will be inappropriate: 
(35) $\xi \xi \xi n$, iran tié èbé 'yes, they are reading a book'
yes they read book

The information provided in (35) is about what the subject noun is doing but the information sought in (33) is about èbe 'book'. The unacceptability of (35) arises from the fact that Edo does not permit the placement of emphatic stresses on elements with a view to bringing them into focus.

3.1.3. Alternative question formation. Alternative questions are formed by conjoining two or more sentences by the alternative conjunction ra 'or'. One sentence contains an assertion and the other negates it or contains a different assertion.

(36) Ivié kùu rà $\emptyset$ vię?

'is Ivie playing or is she crying?'

Ivie play or-Q she cry

In (36) the conjunction ra is glossed as 'or- $Q$ ' because it performs a dual role of conjoining two sentences and question marking. However, the second sentence is commonly deleted and in such cases the question ends with rà. It then functions as a tag and it is in this form that we can rightly call this question-type a polar question. The tag functions as the only question marker $(\mathrm{Q})$ in the following example:

(37) Uyi ghá kpè ókpán rà?

'should Uyi wash the plate?'

Uyi AM wash plate $Q$

Although yi and rà are both tag question formatives, they elicit slightly different responses. Respondents are only expected to agree or disagree with the assertion contained in the formation with $y^{\prime}$ but in the case of questions formed with rad, apart from agreeing or disagreeing with the assertion of the questioner, the respondent can make an alternative assertion. If focussing occurs the respondent is further required to respond in a focus construction. For example, if the subject noun of (37) is in focus it will become:

(38) Uyì (è ré) $\phi \quad$ ghá kpè ókpán rà?

Uyi it be PRO AM wash plate $Q$

'is it Uyi that should wash the plate?'

An appropriate negative reply will be as follows: 
(39) द̧б, èi ré Uyyi $\emptyset$ ghá kpè ókpán

no it-NEG be Uyi PRO AM wash plate

'no, it is not Uyi that should wash the plate'

Focussing, as we have seen so far in polar questions, is an optional device for bringing some constituents into prominence. It determines the natural response of hearers. However, focussing is obligatory in the non-polar questions we shall now examine.

3.2. Non-Polar questions. There are about six methods of forming non-polar questions in Edo. The division is based on the types of question words that occur in them. However, as we shall discover shortly, some of these methods are only alternative ways of asking for the same information. The question particle $y \hat{i}$ (see 3.1.2. above) optionally occurs sentence-finally in all non-polar questions and in such cases, interrogation is doubly marked. We shall, however, ignore this particle here because it adds nothing to the semantic interpretation of such questions.

3.2.1. $d e+N P+S$ formation. All Edo noun phrases including independent pronouns can be questioned by preposing the question particle dè to them, and then the information sought about the noun phrases is contained in relative clauses that follow them. Dè translates as 'what', 'which', 'who', 'when', 'where', and so on, depending on the context of use and the noun phrase that follows it. For example:

(40)
a. dè èhé...?
'where?'
what place
b. dè èghè...? 'when?'
what time
c. dè èmwí...? 'what (thing)?'
what thing
d. dè òmwá...? 'who (sg.)?'
what person
e. dè èmwa...? 'who (pl.)?'
what persons

Relative clauses which obligatorily follow $d e ̀$ and the noun phrase are formed in the same manner focus constructions are formed. Schachter [1973] observes 
that there are striking similarities between focus constructions and relativization in a number of unrelated languages.

In the formation of Edo relative clauses, noun phrases are moved leftward and they are followed by the relativizer (REL) nè which introduces the clauses. If a subject noun is moved, a pro-copy obligatorily fills the extraction site but if an object noun is moved no pro-copy occurs. For example, from the simple declarative sentence in (41a) below, the relative clauses in (41b) and (41c) can be derived.

a. Osàzẹ bọ dwá Osaze build house

b. Osàzé nè $\oint$ bழ owá... Osaze REL PRO build house

c. dwá nè Osàzę bọrè... house REL Osaze build+Past
'Osaze built a house'

'Osaze who built a house ...'

'a house which Osaze built...'

Of course, (41b) and (41c) do not make complete sense; in fact, they are complex noun phrases. When dè is preposed to them, they are transformed into meaningful questions as follows:

a. dè Osàzé nè $\emptyset$ bழ owá? which Osaze REL PRO build house

'which Osaze built a house?'

b. dè òwá nè Osàzẹ bọrè?

which house REL Osaze build+Past

'which house did Osaze build?'

A natural response to these questions must be in focus constructions. For example, (43a) and (43b) below are appropriate responses to (42a) and (42b) respectively.

(43) a. Osàzẹ nè òsè mwẹ (è ré) $\emptyset$ bழ owá Osaze REL friend my it be PRO build house 'it is Osaze who is my friend that built a house' 
b. dwá nà (è ré) Osàzé bọrè

house this it be Osaze build+Past

'it is this house that Osaze built'

3.2.2. $\varangle \nabla b \varangle \delta+S$ formation. Plural human nouns are questioned by the use of ávbáb 'who (pl.)' or ávbá as the young generation of Edo speakers often say. There are syntactic correlations between the use of ávbé as a pluralizer and ávbáo as an interrogative pronoun. 6

We call it an interrogative pronoun because unlike de which is preposed to the noun questioned, ávbá or ávbá is a pronominal replacive for the persons questioned. It is an alternative way of saying dè èmwa 'what persons' or 'who (pl.)' which occurs in (40e) above.

Focussing is overt when ávbáb or ávbá is used in questioning. In fact, the focus marker è ré or $\dot{\phi}$ ré can optionally occur after this interrogative pronoun. For example:
a. ávbáo (è ré) ò kpòlo?
'who is sweeping?' who (pl.) it be PRO sweep
b. ávbá (è ré) Òzó tiè? who (pl.) it be Ozo call
'who is Ozo calling?'

The pro-copy occurs in (44a) because a subject noun is questioned, but it does not occur in (44b) because an object noun is questioned.

3.2.3. $\nabla b e+S$ formation. A variety of questions can be formed by the use of vbè which translates as 'what', 'where', 'why' and so on, depending on the context of use. It is used for asking questions about events, activities, conditions, reasons, locations, and so on.

An aspectual marker a usually occurs in this question-type and it is the tone this marker bears that determines the aspect. A high tone marks the progressive and habitual aspects while a low tone marks the past. It occurs after the subject noun of the sentence that follows vbè. However, when $\varphi$ 'he/she/it' occurs as the subject pronoun, this aspectual marker assimilates to $Q$. For example,
a. vbè i á ré?
'what are you eating?'
what you(sg) ASM eat

\footnotetext{
6For a detailed discussion of the use of ávbé as a pluralizer, see Qmoruyi [1986c]. We have now realized that what we call a pro-copy in this paper cannot be derived from the focus marker $\phi r e$ 'it be' as we suggested in that paper.
} 

b. vbè Òsàró à ré?
what Osaro ASM eat
'what did Osaro eat?'
$\begin{array}{llll}\text { c. vbè } & \phi & \wp & \text { ré? } \\ \text { what he } & \text { ASM eat }\end{array}$
'what is he eating?'
$\begin{array}{llll}\text { d. vbè } & \dot{\partial} & \dot{ } & r e ́ ? \\ \text { what he } & \text { ASM eat }\end{array}$
'what did he eat?'

Adjectival or quality verbs are usually questioned by the following sentence:
(46) vbè $\phi े$
yé hęę?7
'how is it like?'
how it ASM be $Q$

Focussing appears to have occurred in this question-type because vbè is an interrogative pronoun which replaces something or someone about which information is sought by the questioner. This thing or someone is brought into focus in a sentence-initial position. A more appropriate response to (45a), for example, will be (47a) below, while (47b) will be inappropriate even though it is grammatical.
a. ìyán (è ré) ì ré yam it be I eat
'it is yam that I am eating'
b. i mi i yán
I eat yam
'I am eating yam'

Note that the verb mi 'eat' is realized as re 'eat' when it is not followed by a direct object.

3.2.4. gha $+\mathrm{S}$ formation. The interrogative pronoun ghá 'who' questions singular and plural human nouns. It therefore combines the questioning roles of dè $\dot{\phi} m w a ́$ and dè èmwá in (40d) and (40e) respectively, and also ávbáó which is discussed in 3.2.2. above. This means that whenever a questioner employs gha 'who', he is either requesting information about one person or more than one person, or he is not sure about the number of persons. For example:
(48) gha 6
tớtà yè ágá?
'who sat on the chair?'
who PRO sit on chair

7The particle hęe is a question marker which accompanies vbè when it denotes 'how'. 
We observe again that focussing is overt in this question type. The pro-copy $\phi$ occurs in (48) because a subject noun is focussed and questioned. It does not occur when an object noun is questioned as in the following example:

(49) ghá Odúwà támà? 'who did Oduwa tell?' who Oduwa tell

3.2.5. Inu $+\mathrm{S}$ formation. The word inu 'how many/much' questions the quantity of nouns. It can be used with reference to both count and non-count nouns. For example:

(50)
a. inư èghè ...?
'how much time ...?'

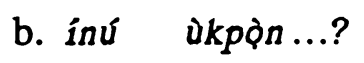
'how many clothes ...?'
c. înú àmè ...?
'how much water ...?'
d. inu dwá...?
'how many houses ...?'

In sentence structures, inú co-occurs with the noun it questions so it is not an interrogative pronoun. However, unlike dè, inú can be uttered in isolation if there is a previous mention of the noun being questioned or it is present in the context of speech. Nouns questioned by inú are always in focus as in the following examples:
a. inú
ikẹ̀kẹ
(è̀ ré) $\grave{Q}$
rré èvbá how-many bicycles it be PRO be there
'how many bicycles are there?'

b. inú ighó (è ré) Osàgié rhié mẹ?? how-much money it be Osagie give me 'how much money did Osagie give me?'

3.2.6. Formation with $\nabla b \partial \delta$. The question particle vbdo immediately follows elements about which information is sought by the questioner. This question-type is, however, usually two ways ambiguous, especially when vbò is preceded by a noun phrase. The questioner may seek information about the location or the state or well-being of the noun phrase. It becomes a "how-question" in the latter interpretation. For example: 
(52)
a. ivbi ruę vbòb?
'where/how are your children?' children your where/how

b. né èbé vbòo? 'where/how is the book?' ART book where/how

In fact, (52a) commonly occurs in Edo greetings and the following responses are both appropriate:
a. iràn rré dwá
they be house
'they are at home'
b. ègbé rhàán íràn
'they are well' body well them

If the questioner specifically wishes to know the location and exclude information about the well-being of the questioned noun phrase, the dè $+\mathrm{NP}+\mathrm{S}$ formation is adopted as follows:

(54) dè èhé nè i vbí rué yé? 'where are your children?' what place REL children your be

Only (53a), for example, will be an appropriate response to (54). It is in this question-type that the interrogative adverb of 'where' as in English is unambiguously expressed in Edo. Focussing can only be said to have occurred in (52) because the element about which information is sought occurs sentence-initially.

\section{Conclusion}

Focussing plays a significant role in determining the information a speaker wants to give or elicit from the hearer. This is achieved in Edo by bringing some sentence constituents into prominence. Other syntactic changes which occur have been examined.

Through focus constructions, Edo speakers are able to form different questions in such a manner that the specific information they wish to elicit from the hearer closely follows the constituent in focus. The derivational processes of these questions and their semantic interpretations have been carefully examined. 


\section{REFERENCES}

Agheyisi, Rebecca N. 1986. An Edo-English Dictionary. Benin City: Ethiope Publishing Corporation.

Amayo, Airen. 1975. "The structure of verbal constructions in Edo (Bini)." The Journal of West African Languages 10(1):5-27.

Amayo, Airen and Ohi Elugbe. 1983. "Edo orthography." In Kay Williamson (ed.), Orthographies of Nigerian Languages, Manual II, pp. 1-11.

Awoyale, Yiwola. 1985. "Focus as an unbound movement rule in Yoruba." Journal of the Linguistic Association of Nigeria 3:75-83.

Bamgbose, Ayq. 1967. A Short Yoruba Grammar. Ibadan: Heinemann Educational Books (Nig.) Ltd.

Elugbe, B.O. 1979. "Some tentative historical inferences from comparative Edoid studies." KIABARA; Journal of Humanities, Volume 2, Rains issue, pp. 82-101.

Emenajo, Nolue. 1979. "Some aspects of interrogation in Igbo." KIABARA: Journal of Humanities, Volume 2, Harmattan issue, pp. 102-112.

Ompruyi, Thomas O. 1986a. "Adjectives and adjectivalization processes in Edo." Studies in African Linguistics 17:283-302.

Ompruyi, Thomas O. 1986b. "Pronominalization and reflexivization in Edo." Afrika und Ubersee 69:81-93.

Omoruyi, Thomas O. 1986c. "Pluralization strategies in Edo." Journal of West African Languages 16(2):61-75.

Qmpruyi, Thomas O. 1988. "On the formation of questions in Edo." Journal of African Languages and Linguistics 10:19-31.

Quirk, Randolph et al. 1972. A Grammar of Contemporary English. London: Longman Group Limited.

Safir, Ken. 1986. "Relative clauses in a theory of binding and levels." Linguistic Inquiry 17:663-689. 
Schachter, Paul. 1973. "Focus and relativization." Language 49:19-46.

Welmers, W. 1973. African Language Structures. Berkeley: University of California Press. 